\title{
People of the Mangrove: A Lens into Socioecological Interactions in the Ecuadorian Black Pacific
}

\author{
Yairen Jerez Columbié \\ ittps://orcid.org/0000-0001-5186-6494
}

University College Cork \& Trinity College Dublin, Ireland

\begin{abstract}
Adapted to survive in the interface between land and sea, mangroves are highly vulnerable to the impacts of climate change. They are also highly adaptive to the imagination, with the theme of the mangrove being differently signified across texts, languages and communities as a place to find death in the tropics, a nature tourism destination, endangered environment, magical wood, refuge for maroons and revolutionaries, and source of livelihoods. The cultural malleability of mangroves mirrors their natural adaptability. It also echoes the varied and rhizomatic identities and imaginaries of the peoples of the tropical Americas. Relevant cultural texts produced in the region support experimentations with mangroves as a raw material susceptible to being worked in order to explain diverse realities. In order to highlight the relevance and malleability of mangrove ecosystems, this paper explores resignifications of socioecological interactions at the Ecological Mangrove Reserve Cayapas-Mataje in Ecuador through the lens of photographer Felipe Jácome. Jácome's photographic essay Los Reyes del Manglar [The Kings of the Mangrove] provides rich material to study the rhizomatic evolution of the theme of the mangrove and its entanglements with people's lives, cultures and histories. I argue that cultural representations of mangroves can go beyond their metaphorical recovery to support environmental justice. This essay is also informed by extant research on the important role of mangrove forests for carbon sequestration and climate change mitigation, which locates these socioecological systems at the centre of people's struggle for climate justice.
\end{abstract}

Keywords: environmental justice, climate change, mangroves, rhizomes, socioecology, Black Pacific, Ecuador

eTropic: electronic journal of studies in the tropics publishes new research from arts, humanities, social sciences and allied fields on the variety and interrelatedness of nature, culture, and society in the tropics. Published by James Cook University, a leading research institution on critical issues facing the world's Tropics. Free open access, Scopus Listed, Scimago Q1. Indexed in: Google Scholar, DOAJ, Crossref, Ulrich's, SHERPA/RoMEO, Pandora. ISSN 1448-2940. Creative Commons CC BY 4.0 free to download, save and reproduce. To cite, include: Author(s), Title of Paper, Editors (Eds.) Special Issue Title (Special Issue) eTropic, volume, issue, year, pages and DOI: http://dx.doi.org/10.25120/etropic.20.2.2021.3808 
eTropic 20.2 (2021) Special Issue: Tropical Imaginaries and Climate Crisis

\section{Mangroves of the Black Pacific}

I

$\mathrm{n}$ the Americas, mangroves stretch from the US, Mexico and the Bermuda Islands in the north, to Peru and Brazil in the south (Spalding et al., 2010). They are 1 present in the Pacific, Atlantic and Caribbean coasts. Even though a comprehensive history of mangroves in the Americas is still pending, an analysis of their fragmented depiction in artistic, historical and scientific texts can contribute to deepening an understanding of their past, present and future roles within both the natural and cultural realms of the region. In mangrove forests, land, freshwater, and the sea converge, which makes these ecosystems simultaneously highly productive, adaptable, and vulnerable to climate change. Climate change is disrupting natural adaptive processes and the acceleration of sea level rise, increased storminess, altered precipitation regimes, and increasing temperature, is impacting mangroves significantly at regional scales (see Ward et al., 2016). Nevertheless, mangrove socioecological systems are not mere victims of global warming, they are also important self-regulating components of the environment and can store three to four times more carbon than land forests (Nyanga, 2020). Carbon sequestration describes the process of capturing carbon dioxide - the most produced greenhouse gas causing climate change - from the atmosphere and storing it. Mangroves' key role in biologic carbon sequestration heightens the importance of their conservation in the context of global climate change and the acceleration of risks for lowlands and people whose vulnerability has been increased by sociohistorical inequalities (IPCC, 2018). Although archaeozoological evidence shows that mangroves were already used by the inhabitants of the Americas for at least 700 hundred years before European colonisation (Wake \& Key, 2013), the negative impact of colonial processes of expropriation and slavery on these and other interrelated ecosystems was immense. Post-conquest deforestation prevailed until the late $20^{\text {th }}$ century and, despite increasingly positive attitudes towards conservation from the 1990s onwards, mangroves have continued to decline (Duke et al., 2007; see also Friess et al., 2020). Although global warming may expand the geographic limits of mangroves to temperate regions, sea level rise, extreme weather events, commercial exploitation, and pollution are threatening their existence (Feller et al., 2017). Coastal construction, aquaculture and vegetable carbon production have been amongst the main exploitation practices leading to an estimated loss of 'over a quarter' of the world's original mangrove woods (Duke et al., 2014, p. 1).

As early as the $16^{\text {th }}$ century, Gonzalo Fernández de Oviedo y Valdés (1526/1851) translated the abundant tropical nature of the Americas into a baroque inventory of commodities in his Historia general y natural de las Indias [General and Natural History of the Indies]. A chapter entitled Mangle (mangrove): "About the so-called mangrove and its fruits and the gains and utilities that can be obtained from it", focuses on the 
eTropic 20.2 (2021) Special Issue: Tropical Imaginaries and Climate Crisis

uses of the "strange" and "admirable" tree (1526/1851, p. 338). For Fernández de Oviedo, mangroves were mainly a source of wood for construction and bark for leather tanning. His description of their fruit as a "brutal food, for savages" (1526/1851, p. 139), highlights its uselessness for European palates and becomes a discourse tool for othering the first inhabitants of the Caribbean, who considered the fruit beneficial and therefore occasionally ate it despite its bitter taste. The fact that this colonial text is the first known written account of human relationships with mangroves in the Americas, is another example of the knowledge loss provoked by colonisation. Fernández de Oviedo's account is written from a colonial lens over a backdrop of violence that led to the almost total extermination of the indigenous cultures of the Antilles. This text's focus on the utility and commercial value of the environment of the Americas is aligned with other colonial depictions of what expeditions 'found' - from Christopher Columbus' 1492 journal onwards (see Columbus \& las Casas, 1492/2011). The utilitarian approach of these first chronicles of the interactions of European colonisers and settlers with the flora, fauna and peoples of the Americas, reveals the wider extractive agenda that would continue to dominate and shape ideas of usefulness across the Atlantic. Between the $16^{\text {th }}$ and late $20^{\text {th }}$ century, "for more than 400 years, colonial and republican use of mangrove wood was governed only by profit maximisation, causing widespread deforestation" (López-Angarita et al., 2016, pp. 154-155). Within this continuous sociohistorical framework, shaped by colonisation, slavery, and post-colonial nation-making, the usefulness of mangroves as sources of wood, vegetable coal, and land for agriculture and construction, has eclipsed both their ecological and cultural significance.

The mangroves of the Black Pacific provide significant lessons on the intertwined ecological and cultural impacts of colonisation. Most of the inhabitants of the CayapasMataje mangrove reserve are black Ecuadorians who have been historically marginalised within both nation-making processes and historical accounts. This mangrove reserve is part of the geo-cultural space that Heidi Feldman (2006) has defined as the Black Pacific, which encompasses less visible histories of enslaved Africans forced to continue their voyage beyond the spaces included in Paul Gilroy's Black Atlantic (1993). Feldman locates the Black Pacific in Peru and, tentatively, other areas along the east coast of the Americas, including territories in Ecuador, Bolivia, Chile and Colombia, where the history of slavery and the cultural expressions of African descent are often neglected. As she states: "Within the Black Pacific, where ideologies of whitening and mestizaje shade the racial imagination (and where larger indigenous populations typically survive), people of African descent are often socially invisible and diasporic identity is sometimes dormant" (Feldman, 2006, pp. 7-8). By approaching the Cayapas-Mataje mangrove as a "racialized landscape" (Leal, 2018, p. 10), this essay brings together decolonial and ecocritical perspectives to look at a socioecological system shaped as much by intertwined racist and extractivist colonial 
eTropic 20.2 (2021) Special Issue: Tropical Imaginaries and Climate Crisis

agendas as by its peoples' resilience. Although originally used to describe the socioecologial realities of the Colombian Black Pacific, a region naturally connected to the Cayapas-Mataje reserve in north Ecuador's Black Pacific (see Figure 1), Claudia Leal's "notion of racialized landscapes can have wide use beyond the Pacific lowlands, for it draws attention to the connections between humanized environments and racialized social groups past and present” (Leal, 2018, p. 228). As highlighted by Leal, most opportunities for black people to have access to land in the Americas arose far from, or on the peripheries, of the plantation world; for this reason, the study of the Pacific lowlands provides insights about an insufficiently investigated postemancipation black peasantry that achieved a certain degree of autonomy. This new information is valuable also for understanding similar processes in portions of land that, after being deemed useless by colonisers and settlers in the Caribbean, were occupied by racialised communities (see Chwala, 2019). In this light, I propose to look at the territory of the Cayapas-Mataje mangrove in Ecuador as a cultural extension of the Caribbean region - and vice versa - to study how the histories of both the Black Pacific and the Black Atlantic converge. It is from these positionings of simultaneous marginality and empowerment that the subjects of the photographic essay Los Reyes del Manglar [The Kings of the Mangrove] — translated into English as Lord of the Mangrove - interrogate Felipe Jácome's camera. In the following sections I discuss how, through these images, the photographed subjects reaffirm their position as key actors within the Cayapas-Mataje mangrove ecosystem.

Figure 1. Map of Ecuador

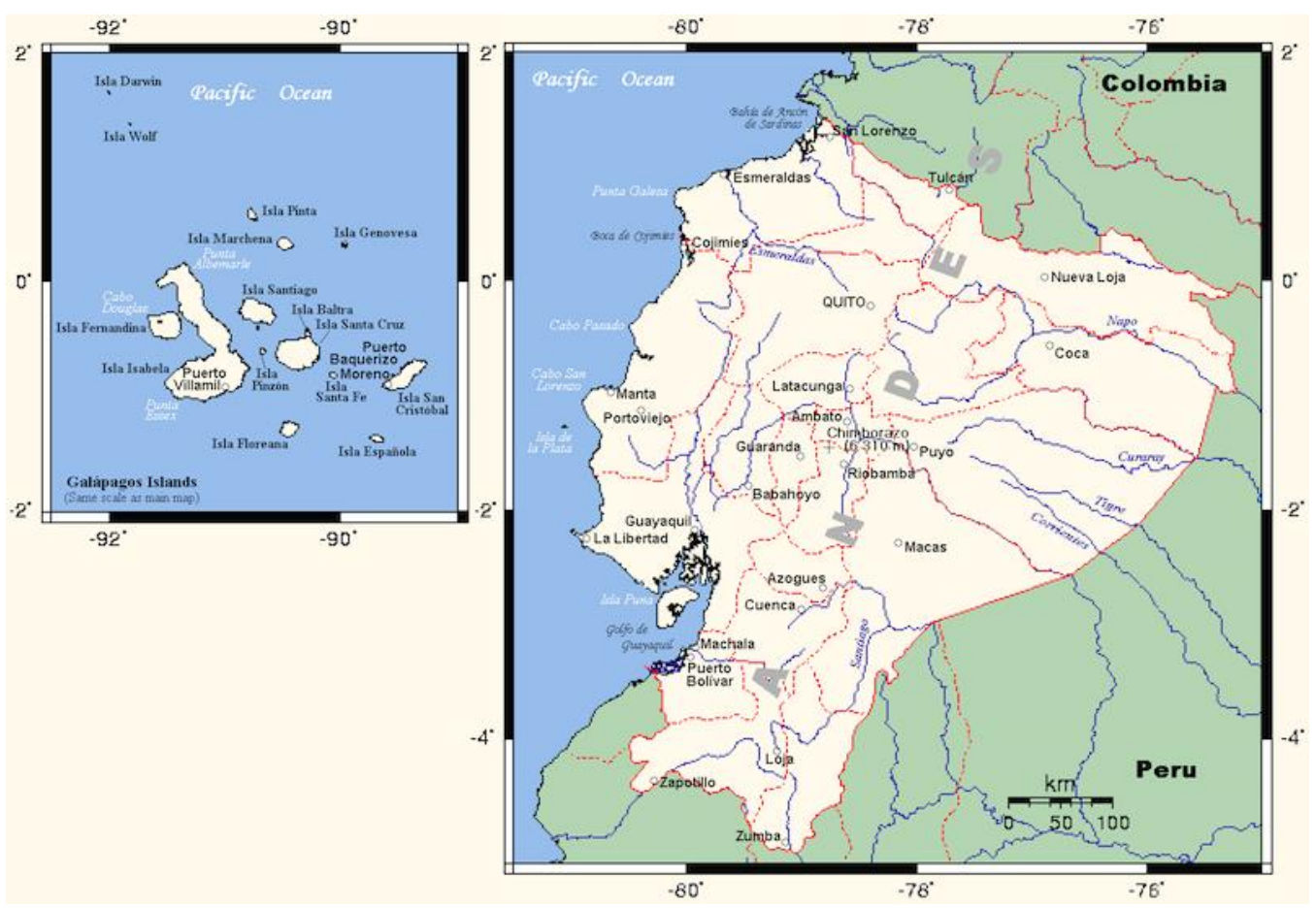

Source: Kelisi Wikipedia, Creative Commons 
eTropic 20.2 (2021) Special Issue: Tropical Imaginaries and Climate Crisis

I propose a thematic critical analysis that engages with regional critical theory and histories to highlight the important role of cultural analyses, literature and visual arts, particularly photography, in addressing environmental justice challenges. Ultimately, my analysis echoes the call to consider the mangrove swamp as one of the "sites of environmental opposition to the plantocracy" (DeLoughrey et al., 2005, p. 3). This is aligned with my preference for either the terms 'Plantationocene' and 'Capitalocene' over 'Anthropocene' to name the current era (Altvater et al., 2016; Haraway, 2016). Unlike the latter, both 'Plantationocene' and 'Capitalocene' acknowledge the role of the plantation system and capitalism in shaping the unequal role of human communities in causing environmental degradation and suffering its consequences. In the same vein, my analysis is aligned with Rob Nixon's (2011) critique of the "slow violence" of narratives that reduce complex environmental issues to simplified accounts that "percolate through science, legislation, policy and civic action [and] can drown out rather than open up possibilities for novel social-ecological engagements" (Lidström et al., 2016, p.1). This article also draws upon research that highlights the potential of the social and human sciences within transdisciplinary perspectives to improve our understanding of socioecological dynamics across temporal and spatial scales (Singh et al., 2013). The following sections are informed by Marisol de la Cadena's (2015) call to rethink difference in ontological terms in order to explore how shared modes of human understanding interpret different yet entangled worlds. Her collaboration with Andean peasants Mariano and Nazario Turpo exemplifies the importance of learning from subaltern people and their environments, an invitation that is also present in Felipe Jácome's photo essay. Furthermore, Los Reyes del Manglar [The Kings of the Mangrove] provides rich material to study the rhizomatic and relational evolution of the theme of the mangrove in the Americas. ${ }^{1}$

\section{Structure of an Imaginary of Relations}

Caribbean philosopher and writer Édouard Glissant's first-hand interactions with the mangrove of the city of Lamentin in Martinique, informed his invitation to recycle Deleuze and Guattari's (1987) metaphor of the rhizome to understand a "Poetics of Relation, in which each and every identity is extended through a relationship with the Other" (Glissant, 1997, p. 11). As a network spreading through the air, the sea and the land, the mangrove sets the ground for Glissant's archipelagic thinking of both the

\footnotetext{
${ }^{1}$ Felipe Jácome is an Ecuadorian photographer whose work focuses on issues of human mobility and human rights. In 2010 he won the Young Reporter Competition of the International Committee of the Red Cross (ICRC). Jácome's photos have appeared in publications such as National Geographic, The Washington Post, Foreign Policy Magazine, The Guardian, Vice Magazine and CNN, and have been exhibited in London, Geneva, Amsterdam, Quito, La Paz and Washington DC. In 2019 Jácome was selected by World Press Photo for the 6x6 Global Talent Award for South America. Jácome's (2019a) photo essay combines portrait and landscape photography and is available online with captions in English.
} 
eTropic 20.2 (2021) Special Issue: Tropical Imaginaries and Climate Crisis

relations between the islands and the peoples of the Caribbean, and their exchanges with other places, cultures, identities and poetics or imaginaries. In this light, mangroves' rhizomatic roots and branches have become tools to explain the relational nature of the cultures of the Caribbean. The region is the nucleus of the tropical Americas and the cultural, social and ecological context that Antonio Benítez Rojo described as a "meta-archipelagic text, a confluence of marine flowings that connects the Niger with the Mississippi, the China Sea with the Orinoco, the Parthenon with a fried food stand in an alley in Paramaribo" (Benítez Rojo, 1996, p. 16). This poetics of relations in which identities evolve through a relationship with the other is well illustrated by the intricated interdependencies and evolutive processes that have shaped mangrove ecosystems, as well as by the cosmogonies of peoples who are a constitutive part of the socioecological systems of the Americas. Lydia Cabrera's (1954) ethnographic studies and conversations with Afro-Cuban religious leaders in the book El Monte [The Forest] collected some of the learnings of Afro-descendant communities, in which a relational poetics between humans and the rest of nature is passed down to the new generations through oral stories, chants, prayers, ceremonies and offerings. In this relationship, the forest is a sacred place and harvesting is done with the permission of the orishas (deities of the Yoruba people); trees are the sacred home of gods and a dwelling place for spirits; herbs cure human ailments, clean the house and the body; and fruits and flowers are some of the most common offerings. Diverse Afro-American religious practices across countries and regions in the Americas today share an origin in the (re)creation of a new Afro-American world by slaves and their descendants, who used both memory and nature as their main materials. These processes of cultural change of people who were deprived from their ancestral material culture — as studied by Rómulo Lachatañeré (1939) in Cuba, Manuel Zapata Olivella (1989) in Colombia, and John Antón-Sánchez (2014) in Ecuador - have a common focus on repositioning humans in a new world. This means that Afro-descendants have been relocating themselves within their environment, where the physical and spiritual realms coexist (see Montgomery, 2019). Both the unity and the diversity of Afro-American religious practices, in which plants are central, exemplify the rhizomatic evolution of cultures in the region in binding relationship with their diverse landscapes.

As acknowledged by philosopher Michael Marder in his introduction to the book PlantThinking, "non-Western and feminist philosophies contain a wealth of venerable traditions much more attuned to the floral world than any author or mainstream current in the history of Western thought" (2013, p. 6). When anthropologist Eduardo Kohn (2013) develops the claim that all living beings, and not only humans, think, and proposes an anthropology beyond the human, he is echoing the beliefs and the knowledge of black and indigenous peoples of the Americas, whose diverse and complex cosmogonies converge in the idea that the human and the divine exist mainly 
eTropic 20.2 (2021) Special Issue: Tropical Imaginaries and Climate Crisis

in their relationship with, and as part of, nature. One of the main contributions of Kohn's work to the task of decolonising academia's relationship with the environment and with subaltern epistemologies, is that it scholarly articulates what its subjects of study know and do. Kohn's translation of subaltern epistemologies into the language of academia to propose a new anthropology beyond the human, is both a successful decolonising endeavour and a symptom of the colonially imposed hierarchies in which ancestral knowledge practices still achieve legitimacy mainly through academic discourse. It would be important then to ask who is "we" when Kohn's says that "we are colonized by certain ways of thinking about relationality" (2013, p. 21). Whereas Kohn focuses on how changing "our" approach to key epistemological and ontological questions can reshape "our understanding of relationality and 'the human"' (2013, p. 72), both Anna Tsing (2015) and Rosi Braidotti (2019) send an invitation to explore diverse ways of being human while rejecting the universalist "we". Anna Tsing (2015) takes Kohn's critique of anthropocentrism a step further in her interrogation of the concept of the notion of the Anthropocene, which neglects the different ways in which humans relate to and are part of the environment: "This 'anthropo-' blocks attention to patchy landscapes, multiple temporalities, and shifting assemblages of humans and nonhumans: the very stuff of collaborative survival" (Tsing, 2015, p. 20, see also Tsing et al., 2020). Thinking critically about the environment entails acknowledging that Eurocentric humanism has blind spots and that the concept of the Anthropocene is both universalist and misleading. This is aligned with Rosi Braidotti's invitation to assess the human as "materially embedded and embodied, differential, affective and relational" (2019, p. 11). Understanding the human as materially embedded requires taking distance from abstract universalisms and looking closer at the material context of subjects and their relations. In the same vein, assessing the human as embodied calls for paying attention to people's lived experiences. Viewing the subject as differential implies acknowledging the value of subaltern epistemologies, which contradict the dominant Anthropocene discourse. It is equally important embracing Braidotti's emphasis on affectivity and relationality as ways of seeing people as part of the complex networks of all that lives and both suffers and resists commodification. Assessing the human as affective and relational connects centrally with the ethics of care that guide the eco-territorial, ecofeminist and intersectional struggles in Latin America (see Gabiola, 2020). For Braidotti, as for many indigenous and Afrodescendant peoples in the Americas, humans are in practice "eco-sophical entities", part of webs of connections, negotiation, and collaboration "within the nature-culture continuum" (Braidotti, 2019, p. 47; see also Latour, 2009). As she notes, "the posthuman predicament, with its upheavals and challenges, gives the opportunity to activate these alternative views of the subject against the dominant vision" (Braidotti, 2019, p. 12). Relatedly, Michael Marder (2013) envisions a method drawn from the plants themselves and a discourse rooted in them. These theories and epistemologies, along with Marder's method, are guides to my reading of Felipe Jácome's rhizomatic 
eTropic 20.2 (2021) Special Issue: Tropical Imaginaries and Climate Crisis

immersion in the Cayapas-Mataje mangrove reserve and the questions to ask of his photo essay.

Could mangroves' interdependencies with other ecosystems and their own internal symbiotic relationships provide useful metaphors to support a poetics of relation that goes beyond humans? Could these and other ecosystems teach diverse human groups to forge more reciprocal socioecological interactions? Studies show that "together, mangroves, corals and seagrasses provide more protection services to both humans and non-humans than any individual habitat or any combination of two habitats" (Guannel, et al., 2016, p. 1). Their entangled existences illustrate a poetics of relation that continues to be negatively impacted by some humans' activity, regardless of ongoing conservation initiatives such as those under the umbrella of global agreements, conventions and programs such as the Convention on Biological Diversity, Convention of the International Trade of Endangered Species (CITES), Convention on Migratory Species, Ramsar Convention, UNESCO Man and Biosphere Program, UNESCO World Heritage Convention, United Nations Framework Convention on Climate Change (UNFCCC), and the Kyoto Protocol. Extant research highlights the imperative of integrating a cultural perspective within existing ecological and economic mangrove management approaches in order to achieve an integrated management of ecosystem services that truly benefits people (see Queiroz et al., 2017). This approach is complemented by recent studies on ecosystems 'disservices', understood as negative interactions between humans and ecosystems, which show how contemporary perceptions and uses of mangroves are influenced by sociohistorical processes that have disconnected people from their environment (Friess, 2016, p. 183).

The cultural uses of mangroves also show the diversity of theoretical perspectives that are mediated by the realities of the tropical Americas across diverse territories, cultures and languages. Intellectuals from the region have been engaging with mangroves not only through critical theory, as highlighted earlier, but also through forms of narrative fiction that reveal how these ecosystems re-signify relationality in the region. For instance, Eric Prieto (2003) has compared and contrasted uses of the trope of the mangrove swamp in the work of francophone writers Maryse Condé and Édouard Glissant. For Glissant (1981), who focused on the swampy area at the mouth of the Lézarde river in his novel La Lézarde [The Lezarde], the delta marks the point where human intervention aids the river in its descent to the city. Whereas Glissant highlights humankind's place within nature and outlines almost symbiotic humannature relations, Condé (1995) emphasises the density of the swamp in Traversée de la Mangrove [Crossing the Mangrove] as a metaphor for the complexity of Caribbean societies - which interrogates the ability of cultural theorists and writers to fully grasp the intricate sociohistorical processes, imaginaries, and identities of the region. As 
eTropic 20.2 (2021) Special Issue: Tropical Imaginaries and Climate Crisis

Prieto notes of Condé: "The lesson she has drawn from the Caribbean environment involves not the deterministic pressures of natural selection, but rather the irrepressible diversity of nature" (Prieto, 2003, p. 149). Condé's thick mangrove swamp traps people and forces them to interrogate their realities and identities: "You don't cross a mangrove. You'd spike yourself on the roots of the mangrove trees. You'd be sucked down and suffocated by the brackish mud" (Condé, 1995, p. 158).

In the Hispanic Caribbean, more specifically in Cuba, a similar swamp ensnares the characters of Antonio Benítez Rojo's (1997) short story 'Desde el manglar' [From the Mangrove], translated into English as 'A view from the Mangrove'. The awareness of the connections between what Benítez Rojo (1996, p. 16) calls the "rhythms" of a polyrhythmic and polyphonic region is also present in his short story, where spaces and characters from across the circum-Atlantic are both connected and disconnected by a mangrove located in Cuba during the Second War of Independence (1895-1898). As the story develops, the mangrove facilitates the overlapping of memories, possible futures, and the present. The mangrove of Benítez Rojo's short story not only resignifies the main character's personal journey and social relationships; it is also constantly repurposed as either a place to die or to survive, as inhospitable environment, or refuge providing livelihoods away from the horrors of war. Far from offering a conclusive depiction of this ecosystem, the author shows its symbolic malleability, as well as its ability to forge relations of solidarity and new imaginaries; the "vital alternative communities" provided by apparently harsh environments that became places of resistance in the colonial Americas: mountain ranges, provision grounds, caves, and mangrove swamps (DeLoughrey et al., 2005, p. 3). The relevance and malleability of mangrove ecosystems in the imaginaries of the Americas also allow for the resignifications of contemporary sociological interactions within the Ecological Mangrove Reserve Cayapas-Mataje in Ecuador. Moving from literature, we now peer through the lens of photographer Felipe Jácome.

\section{People of the Mangrove are Watching}

The Ecological Mangrove Reserve Cayapas-Mataje harbours a resilient mangrove ecosystem that provides livelihoods for some 6000 people. Whereas fishing and cockle gathering benefit an $85 \%$ of households, the 3000 ha of shrimp farming developed from the 1960 s onwards employs $0.6 \%$ of the population and has led to the destruction of cockle-gathering grounds. A study by Patricia Ocampo-Thomason (2006) shows how local people have been responding to these changes by creating new management strategies, from the creation of mangrove defence groups to the implementation of a stewardship practice they call 'custodias' [guardians] (OcampoThomason, 2006, p. 140). This form of permit guarantees the allocation of mangrove 
eTropic 20.2 (2021) Special Issue: Tropical Imaginaries and Climate Crisis

areas to the communities for their traditional use and management, including cockle gathering, and forbids extractivist practices such as intensive logging and charcoal production. Macarena Gómez-Barris (2017) has brought together social ecologies and decolonial perspectives to explore extractivism in the Americas. The term is used to name extractive capitalism, the economic system based on expropriation and intensive exploitation of environments through colonial and neo-colonial projects. Similarly, Maristella Svampa (2019) has called attention to neo-extractivist practices that focus on new resources, ecosystems or territories, the exploitation of which was considered less profitable in the past. As a result of sustained extractivist and neoextractivist practices, mangrove gatherers in Ecuador live in poverty, with deficient public infrastructure and services, limited access to education, and informal labor patterns in which women and children play an important role.

And the entwined environment of children in these practices is not lost in Felipe Jácome's photo essay. Whereas the title in Spanish, Los Reyes del Manglar, reveals an emphasis on the people's collective management of their land, the use of the singular in the English translation, Lord of the Mangrove, as displayed in Jácome's (2019a) website, calls for an analogy with the novel Lord of the Flies by Nobel Prize in Literature awardee William Golding (1954). Although both Golding's and Jácome's works focus on the children's management of the environment, the ethos of the novel and of the images differ deeply. Published in 1954, when the British Empire moved between retreating and formulating new ways of imperial reassertion (see Lynn, 2005), Lord of the Flies takes its "image of 'savagery' from the classic cultural misrepresentation (Empire-evolved) of white civilisation and black/African barbarity" (Hawlin, 1995, p. 126). A possible reading of the novel reveals that it neglects subaltern forms of civilisation, governance, knowledge and culture, and reproduces the imperial view which justifies conquest through both the principle of terra nullius and the racist idea that only the adult white male, the conqueror, educated within Western civilisation, knows how to manage societies and environments. It is important to recall that European colonialism used the doctrine of terra nullius [empty land] to justify its abolishment of the rights of stateless and first peoples over their land (see Blaser et al., 2013, p. 156). Contrastingly, Jácome's images show the key role of children and teenagers of African descent in shaping socioecological interactions in the Cayapas-Mataje mangrove, the ecosystem of which they are part. While facing the audience with social and environmental injustice by showing the vulnerability of the subjects, the photographic essay also captures how the resilience of these marginalised youth enables them to become the real kings of their own land:

After several years coming back to the mangrove and observing the work, I was seeing a world, a kingdom; I started seeing those children as the owners of this world, which is a world apart, an isolated world, 
eTropic 20.2 (2021) Special Issue: Tropical Imaginaries and Climate Crisis

an unknown world. That is why the photo essay took the name of The Kings of the Mangrove (Jácome, 2019b, n.p.). ${ }^{2}$

Rather than trying to draw conclusions regarding the true motivations behind the translation of the title Los Reyes del Manglar [The Kings of the Mangrove] as Lord of the Mangrove, my analysis focuses on the meanings and resignifications that emerge through the space these different titles open up - whether mere coincidence, neglect of the imperialist tints of Lord of the Flies, or the intentional decolonising appropriation and resignification of Golding's text. Whatever the case may be, the use of this English title in the wider context I described earlier, can be read as transatlantic appropriation that turns an imperial cultural product into a communication tool of the subaltern through an act of cultural translation, in the sense described by cultural theorist Julio Ortega (2006).

In what can be read as an act of support to decolonising appropriations, the photos were exhibited in the Cayapas-Mataje mangrove reserve between 27 July and 20 August 2017. Around 400 persons, including concheros [shell pickers] who were working in the area, as well as neighbours from the communities of Tambillo, Pampanal de Bolívar, Palma Real and San Lorenzo, saw the exhibition (Jácome, 2018). Printed on six-meter-long canvasses, the images hanged from the mangrove trees, enabling a juxtaposition of self-reflecting realities. Felipe Jácome, who has described photography as a dialogue between the photographer and the subject, conceived the exhibition as "an homage to the trees, the ecosystem and the people who work there" (Jácome, 2019b, n.p.). By exhibiting the pictures inside the mangrove, Jácome transcended the act of approaching Afro-descendants as subjects in a sociohistorical context where black people have been treated as objects and commodities. The photographer goes one step further and facilitates their role as spectators. The dual experience of "observed subject" and of "subject observing" opens the possibility for the photographed individuals to participate in the "animation" of the images through their experience as spectators (Barthes, 1980, p. 10).

Although an analysis of Jácome's gaze should not neglect the racist implications of the act of photographing the Other in postcolonial contexts (see Bate, 1993), it should also highlight his attempt to make the voice of the subaltern present in the photo essay by bringing the images back to the mangrove and its people. This is also supported by the brief stories that caption the images on the online exhibition, which reveal a work of ethnographic research (Jácome, 2019a). The written descriptions provide relevant information about the personal stories behind the portraits. It is important to bear in mind that portraiture occupies a critical space within the visual landscape of

\footnotetext{
${ }^{2}$ All translations by the author of this essay unless otherwise stated.
} 
environmental justice; its ability to offer a personalised and affective framework makes it one of the most used genres on photographic websites and exhibitions dealing with environmental injustices (Gabrielson, 2019). However, portrait's long-standing colonial history, the "ambiguities generated by colonial encounters" and the "functions of the portrait within these encounters", should not be ignored (Dell, 2020, p. 192). It is precisely portrait's ambiguity and instability, emphasised by colonial history and postcolonial re-configurations, that makes it susceptible to being re-appropriated by postcolonial subjects. In this light, reflecting on how marginalised subjects participate in, or resist portrayal, could contribute to the ongoing decolonisation of photography (see Dell, 2020).

In Jácome's work low-angle shots highlight the size of the mangrove trees of the Cayapas-Mataje reserve, which are amongst the tallest in the world (Spalding, et al., 2010). One of the photos shows child Cesar Castro in the foreground looking up at the mangrove. He is the only one of eight siblings to pick shells to contribute to the family's income. The zoom on Cesar's face leaves his neck out of the framing and focuses on his features, emphasising the relationship between the child and the mangrove that both surrounds him and reflects on his eyes, in a multiplier photographic effect that accentuates the role of the photographed subject as animator.

Figure 2. Child Cesar Castro

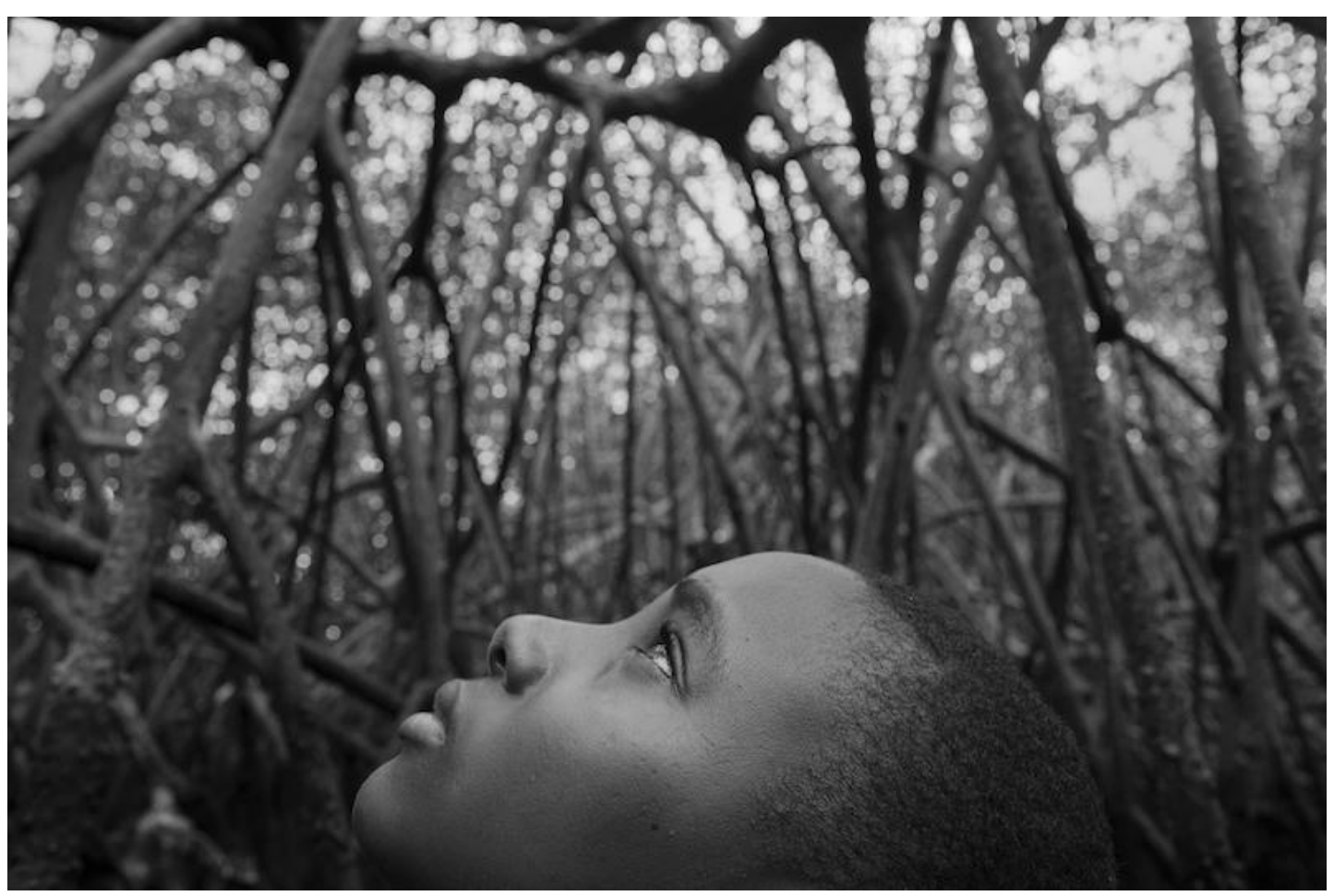

Photograph: Felipe Jácome 2019 https://www.felipejacome.com/lord-of-the-mangrove 
eTropic 20.2 (2021) Special Issue: Tropical Imaginaries and Climate Crisis

Other images capture the agile movements of the children between the mangrove trees of Cayapas-Mataje, but the animation of the photo essay is completed by the stories behind the portraits: Elisa Castillo lives with her aunt and stopped going to school at age 15 to contribute to her household's economy; Soraya Mesa has 9 brothers, 6 of whom pick shells; the kids often come back from picking shells earlier than the adults in order to make it to afternoon school. The photo essay's text explains that although community leaders and local authorities encourage children to stay in school, many drop out of classes to become full-time concheros.

Nevertheless, the children's relationship with the landscape is not limited to work activities; the mangrove is also a natural playground where they swim and catch small animals after work hours, which are determined by the tides. By capturing these other scenes, Jácome joins environmental justice advocates who conceptualise the environment as the place where people live, work, and play (see Gabrielson, 2019). The photographic essay also apprehends the children's close relationship with the fauna of the region: child Efraín Montaño uses two black shells to mimic a second pair of eyes or glasses; Gabriel Benítez holds up a poisonous toadfish, a species that lives in the mud and whose sting can cause infection and deformity in the hands of the cockle gatherers. The ecological reserve Cayapas-Mataje hosts a rich fauna, including 173 bird species, some 53 species of mammals, American crocodiles and caimans and diverse types of fish and invertebrates (Spalding et al., 2010).

Although Jácome's photographs focus on the children and the trees of the CayapasMataje reserve, some images also show the relationships of care between women and their sons and daughters: Rosa Quiñones, who has seven children, bathes her son Efraín; in another image, she carries two of her sons to school during the monthly high tide that floods the communities for several days; another photo shows a baby sleeping in the mother's lap while she plays Bingo with a neighbour; a woman dances with a baby at a community bar. The photo essay captures some of the many dailylived moments when these children and women embody and practice an ethics of care. This ética del cuidado [ethics of care] is a core component of the alternative paradigms that guide Latin American environmentalism, including: Sumak Kawsay (Quechua language) and Suma Qamaña (Aymara language) [partially translatable as Good Living or Living Well]; derechos de la naturaleza [rights of nature]; and bienes comunes [common goods]. In Latin America and the Caribbean, these principles draw mainly upon knowledge practices of indigenous and Afro-descendant peoples. The common discourse of these perspectives expresses ecological, economic, religious, aesthetic, and wider cultural values that subject economic growth to the conservation of all forms of life, the defence of ecosystems, and the maintenance and regeneration of its life cycles (see Svampa, 2019). In Jácome's photo essay, this ethics of care is embodied as much in the mother's body carrying her children to school through a 
eTropic 20.2 (2021) Special Issue: Tropical Imaginaries and Climate Crisis

flooded community, as in the children's hands, which harvest and provide for their siblings, parents and communities. Without neglecting the ethical implications of child labour, the images show children's agency and sense of responsibility towards others. In a recent publication that draws upon indigenous environmental martyr Berta Cáceres' activism, Irune Gabiola (2020) discusses how decolonising affect offers new approaches that dismantle colonially constructed emotions and feelings, while contesting the dichotomy between rationality and irrationality, mind and body. Los Reyes del Manglar contributes to the task of showing the importance of affect in decolonising human relations with all that lives - which is at the core of the principles guiding eco-territorial, ecofeminist and intersectional struggles in Latin America.

The few images including adults show mainly women, and only two men appear, in the background of one photograph, within the entire photo essay. Unlike the photos that portray the children and teenagers with the trees, these images of adults focus on life in the villages, where the lack of infrastructure and services becomes evident. In the reserve, communities are generally small, the smaller the community, the scarcer the facilities and services (Ocampo-Thomason, 2006). The adult population has been forced to negotiate its limited alternatives with the shrimp-farming industry. Patricia Ocampo-Thomason (2006) has studied how, with the expansion of the ponds, locals lost access to certain mangrove areas, wild fisheries started to become scarce, and the population gained more awareness of the negative socioecological impacts of this type of farming. Well-organised grassroots initiatives started in the 1970s linked to Organización Campesina Musine y Esmeraldas OCAME [Peasant Organisation of Musine and Esmeraldas]. The combination of peasant-oriented modes of participation with theology-of-liberation activism led to the creation of Fundación de Defensa Ecológica FUNDECOL [Fundation for Ecological Defence] in 1991. FUNDECOL gave its support to Afro-descendant organisations' claims for inclusion of the northern mangrove ecosystems within the National Protected Areas System and created the Coordinadora Nacional para la Defensa del Ecosistema Manglar C-CONDEM [National Coordinating Committee for the Defence of Mangrove Ecosystem]. Recent developments of this struggle led to the creation of the PAEM [Ancestral Peoples of the Mangrove Ecosystem]. According to Sara Latorre (2013, pp. 67-68), one of the movement's main achievements is that "it has made visible the existence of human populations living within a fragile and threatened ecosystem who wish to continue to live there". A recent study on the impact of shrimp ponds on mangrove blue carbon stocks in Ecuador emphasises the important role that mangrove forests play in mitigating climate change and calls attention to the threats of aquaculture expansion in the region (Merecí-Guamán, et al., 2021, p. 816). Due to both their natural role in carbon sequestration and their cultural meanings as racialised landscapes, the protection of mangrove ecosystems in Ecuador is an important climate justice challenge. A climate justice perspective calls for acknowledging how industrialisation 
eTropic 20.2 (2021) Special Issue: Tropical Imaginaries and Climate Crisis

processes directly linked to colonialism, slavery, and extractivism, have shaped both global warming and inequality (see Jafry, 2018). Supporting climate justice also entails acknowledging the need for "global cognitive justice", by learning from the "epistemologies from the South, a set of... ways of knowing developed by social groups as part of their resistance against the systemic injustices and oppressions caused by capitalism, colonialism and patriarchy" (de Sousa-Santos, 2014, p. x).

People's socioenvironmental struggle in the Cayapas-Mataje reserve is part of the eco-territorial turn in Latin America, which is developing collective frameworks for mobilisation and implementing more reciprocal socioecological interactions and perspectives in support of climate justice. In this context, Felipe Jácome's photos support the task of bringing forth marginalised ecosystems and its people's knowledge practices. His photographic essay is an example of the visual politics of environmental justice in a context where photography had a prominent role as a cultural and political medium to support colonial and racial marginalisation, at least until the first decades of the $20^{\text {th }}$ century (see Hight \& Sampson, 2013). Jácome challenges racialised modes of viewing that depict low-income people and people of colour "either as passive victims or as somehow deserving of the degraded environments in which they live" (Gabrielson, 2019, p. 47).

\section{Entwining Territories, Temporalities, and People}

The trope or theme of the mangrove has been differently signified across texts, languages, and communities as a place to find death in the tropics, nature tourism destination, endangered environment, magical wood, refuge for maroons and revolutionaries and source of livelihoods. This cultural malleability of mangroves mirrors their natural adaptability and echoes the varied and rhizomatic identities and imaginaries of the peoples entangled in the network of histories, roots, seashores, deltas, archipelagos and mainland of the tropical and subtropical territories of the Americas. The plasticity of these ecosystems opens possibilities for articulating new meanings that locate them at the centre of more reciprocal socioecological interactions. Relevant cultural texts produced from within the region support these experimentations with mangroves as a raw material susceptible to being worked and reworked in order to explain the varied and unstable realities of the Americas.

Although extant research on plant art highlights how creators around the globe are bringing forward plant's agency (Macpherson, 2018; Ryan, 2015), more decolonising efforts are required to acknowledge the experiential knowledge of those communities and individuals whose reciprocal and equitable relations with plants have been neglected by Eurocentric humanism and anthropocentrism. As criticised by curator and author Giovanni Aloi, dominant plant art, art history, and criticism, stills favours 
eTropic 20.2 (2021) Special Issue: Tropical Imaginaries and Climate Crisis

the symbolic and the human, even when they try to outline new eco-agendas: "plants can be featured in art, but only through a symbolic register, that makes them meaningful to human affairs. To gain our attention, they have to ventriloquize the transcendental side of the existential" (Aloi, 2018, p. 69). Plant's centrality and agency in the cultural practices of Afro-descendant communities in the Americas contrast with the marginalisation of the vegetable world within Western philosophical discourses (see Marder, 2013). In this light, subaltern peoples' thought, arts, and practices provide valuable empirical information to build a new 'decolonial ecology' (see Ferdinand, 2019). Exploring the arts, lived experiences, and knowledges, of peoples in the margins - as those living in racialised landscapes of Latin America and the Caribbean - can contribute to transcend human-plant relationships in which plants are seen as mere objects of either conservation or aesthetic projects. By capturing vulnerable, yet resilient, trees and humans, and telling their stories both on the web and in the mangrove, Jácome's photo essay proposes a dialogue between photographer, subjects, and plants, which contributes to wider resignifications of the mangrove ecosystems of the Americas as places of resistance and opportunity.

Jácome's work also invites us to look at the subaltern epistemologies of the people, and particularly the children, of the Cayapas-Mataje reserve, who bring forward the importance of mangrove ecosystems through their own lived experiences. These types of immersion in vulnerable socioecological systems are vital for artistic endeavours aiming to support environmental justice, even more so in contexts where climate change accelerates the epistemic violence of imperialist economies, laws, and cultures which both produce and reproduce social realities in which policymakers ignore subaltern voices (see Spivak, 1988). Looking at the histories and cultural representations of the landscape, the vegetation, the fauna, and the humans that live in and shape mangrove ecosystems can contribute to communicating the ecological and cultural relevance of these socioecological systems, which continue to be neglected by extractivist and neo-extractivist agendas. Similarly, establishing a dialogue between readings of the Caribbean and the Black Pacific, which share similar tropical ecosystems and histories, could contribute to articulating new forms of 'translocal' collaboration and solidarity for climate justice (Routledge, 2011, p. 385). The rhizomatic growth of the branches and roots of the mangrove can be understood as a living metaphor of the relations not only between the territories, temporalities and peoples that have differentially shaped and suffered environmental degradation, but also between the communities leading the eco-territorial turn and standing for the rights of nature. Nevertheless, seeing beyond metaphor entails focusing on the life of the mangrove, including the people who work and play in this socioecological system. Their knowledge and values are key to addressing social and environmental justice challenges. 
eTropic 20.2 (2021) Special Issue: Tropical Imaginaries and Climate Crisis

In a global context where conservation initiatives continue to be informed by the dominant Anthropocene discourse's universalist perspective that perceives all humans as the cause of climate change and as a threat to ecosystems, shining a lens on the alternative role of communities as stewards of the environment becomes of vital importance. This is precisely what Felipe Jácome and his photographed subjects do by walking the viewer through the mangrove and showing trees' and people's intertwined daily lives. The shell-pickers' management of their environment in the Cayapas-Mataje reserve contradicts an inefficient and unjust "fortress conservation" approach that, as highlighted by geographer Judith Carney, "ignores an alternative environmental history where traditional user groups have in fact acted as environmental stewards" (Leal et al., 2020, p. 396). By making visible the relations of care between trees and people as a continuum that persists through to the youngest generation, Los Reyes del Manglar shows that it is imperative that conservation initiatives are informed by postcolonial and decolonial environmental histories. Most importantly, these images tell us that the faces, the voices, and the gazes reflecting the past, present, and future of the mangrove also need to be protected, seen, and listened to. 
eTropic 20.2 (2021) Special Issue: Tropical Imaginaries and Climate Crisis

\section{References}

Aloi, G. (2018). Trees: Upside-Down, Inside-Out, and Moving. In G. Aloi (Ed.), Why Look at Plants?: The Botanical Emergence in Contemporary Art, (pp. 69-80). BRILL. https://doi.org/10.1163/9789004375253 007

Altvater, E., Crist, E.C., Haraway, D.J., Hartley, D., Parenti, C., \& McBrien, J. (2016). Anthropocene or Capitalocene?: Nature, History, and the Crisis of Capitalism. PM Press.

Antón-Sánchez, J. (2014). Religiosidad afroecuatoriana. Instituto Nacional de Patrimonio Cultural.

Barthes, R. (1980). Camera Lucida. Vintage Books.

Bate, D. (1993). Photography and the colonial vision. Third Text, 7(22), 81-91. https://doi.org/10.1080/09528829308576403

Benítez Rojo, A. (1996). The Repeating Island: The Caribbean and the Postmodern Perspective. Duke University Press, 1996. https://doi.org/10.1215/9780822382058

Benítez Rojo, A. (1997). Desde el mangler. Revista Cuba Encuentro, spring/summer, 97109.

Blaser, M., McRae, G., \& Feit, H. (2013). In the Way of Development: Indigenous Peoples, Life Projects and Globalization. Zed Books Ltd.

Braidotti, R. (2019). Posthuman Knowledge. Wiley.

Cabrera, L. (1954). El monte, igbo finda, ewe orisha, vititinfinda: Notas sobre las religiones, la magia, las supersticiones y el folklore de los negros criollos y del pueblo de Cuba. Ediciones C. R.

Cadena, M. de la. (2015). Earth Beings: Ecologies of Practice across Andean Worlds. Duke University Press.

Chwala, G. L. (2019). Ruins of Empire: Decolonial Queer Ecologies in Cliff's No Telephone to Heaven. eTropic: Electronic Journal of Studies in the Tropics, 18(1), 141-156. https://doi.org/10.25120/etropic.18.1.2019.3690

Columbus, C. \& las Casas, B. (1492/2011) The Log of Christopher Columbus' First Voyage to America in the Year 1492. Martino Fine Books.

Condé, M. (1995). Crossing the Mangrove (Trans. R. Philcox). Anchor Books, 1995.

Deleuze, G. \& Guattari, F. (1987). A Thousand Plateaus: Capitalism and Schizophrenia. University of Minnesota Press.

Dell, S. (2020). The Portrait and the Colonial Imaginary. Leuven University Press.

DeLoughrey, E., Gosson, R., \& Handley, G.B. (2005). Introduction. In E. DeLoughrey, R. Gosson, G.B. Handley (Eds.), Caribbean Literature and the Environment: Between Nature and Culture, (pp. 1-32). University of Virginia Press.

Duke, N. C., Meynecke, J-O., Dittmann, S., Ellison, A. M., Anger, K., Berger, U., Cannicci, S., Diele, K., Ewel, K. C., Field, C. D., Koedam, N., Lee, S. Y., Marchand, C., Nordhaus, I., \& Dahdouh-Guebas, F. (2007). A World Without Mangroves? Science, 317(5834), 41b-42b. https://doi.org/10.1126/science.317.5834.41b

Duke, N., Nagelkerken, I., Agardy, T., Wells, S., \& Van Lavieren, H. (2014). The importance of mangroves to people: $A$ call to action [Report]. United Nations Environment Programme World Conservation Monitoring Centre (UNEP-WCMC).

Feldman, H. (2006). Black Rhythms of Peru: Reviving African Musical Heritage in the Black Pacific. Wesleyan University Press.

Feller, I. C., Friess, D. A., Krauss, K. W., \& Lewis, R. R. (2017). The state of the world's mangroves in the 21st century under climate change. Hydrobiologia, 803(1), 1-12. https://doi.org/10.1007/s10750-017-3331-z

Ferdinand, M. (2019). Une écologie décoloniale: Penser l'écologie depuis le monde caribéen. Éditions du Seuil. https://doi.org/10.3917/pro.375.0052 
eTropic 20.2 (2021) Special Issue: Tropical Imaginaries and Climate Crisis

Fernández de Oviedo, G. (1526/1851). Historia General y Natural de Las Indias, Islas y Tierra-Firme Del Mar Océano. Primera Parte. Vol. 1. Madrid: Imprenta de la Real Academia de la Historia. https://doi.org/10.5962/bhl.title.17775

Friess, D. A. (2016). Ecosystem Services and Disservices of Mangrove Forests: Insights from Historical Colonial Observations. Forests, 7(9), 183. https://doi.org/10.3390/f7090183

Friess, D. A. et al. (2020). Mangroves give cause for conservation optimism, for now. Current Biology, 30(4), R153-R154. https://doi.org/10.1016/i.cub.2019.12.054

Gabiola, I. (2020). Affect, Ecofeminism, and Intersectional Struggles in Latin America: A Tribute to Berta Cáceres. Peter Lang Publishing, Incorporated.

Gabrielson, T. (2019). The Visual Politics of Environmental Justice. Environmental Humanities, 11(1), 27-51. https://doi.org/10.1215/22011919-7349396

Gilroy, P. (1993). The Black Atlantic: Modernity and Double Consciousness. Verso.

Glissant, E. (1997). Poetics of Relation. University of Michigan Press. https://doi.org/10.3998/mpub.10257

Glissant, É. (1981). La Lézarde: roman. Editions du Seuil.

Golding, W. (1954). Lord of the Flies. Riverhead Books.

Gómez-Barris, M. (2017). The Extractive Zone: Social Ecologies and Decolonial Perspectives. Duke University Press. https://doi.org/10.1215/9780822372561

Guannel, G., Arkema, K., Ruggiero, P., \& Verutes, G. (2016). The Power of Three: Coral Reefs, Seagrasses and Mangroves Protect Coastal Regions and Increase Their Resilience. PLOS ONE, 11(7), 1-22. https://doi.org/10.1371/journal.pone.0158094

Haraway, D.J. (2016). Staying with the Trouble: Making Kin in the Chthulucene. Duke University Press. https://doi.org/10.2307/i.ctv11cw25q

Hawlin, S. (1995). The savages in the forest: Decolonising William Golding. Critical Survey, $7(2), 125-135$.

Hight, E.M., \& Sampson, G.D. (2013). Colonialist Photography: Imag(in)ing Race and Place. Routledge. https://doi.org/10.4324/9781315015262

IPCC (2018). Global Warming of $1.5^{\circ} \mathrm{C}$ : An IPCC Special Report on the Impacts of Global Warming. Intergovernmental Panel for Climate Change.

Jácome, F. (2018). La primera exposición fotográfica en medio de un manglar, contada por el propio autor Vice, 2018, n.p. https://www.vice.com/es/article/qvxpbb/la-primeraexposicion-fotografica-en-medio-de-un-manglar-contada-por-el-propio-autor

Jácome, F. (2019a). Lord of the Mangrove Exhibit, online exhibition (ongoing). https://www.felipejacome.com/lord-of-the-mangrove

Jácome, F. (2019b). Lord of the Mangrove Exhibit, video commentary. https://www.felipejacome.com/lord-of-the-mangroveexhibit.

Jafry, T. (2020). Routledge Handbook of Climate Justice. Taylor \& Francis.

Kohn, E. (2013). How Forests Think: Toward an Anthropology Beyond the Human. University of California Press. https://doi.org/10.1525/california/9780520276109.001.0001

Lachatañeré, R. (1939). El Sistema Religioso de los Lucumís y otras Influencias Africanas en Cuba. Estudios Afrocubanos, iii (1-4)28-84.

Latorre, S. (2013). The Politics of Identification in a Shrimp Conflict in Ecuador: The Political Subject, "Pueblos Ancestrales del Ecosistema Manglar" [Ancestral Peoples of the Mangrove Ecosystem]. The Journal of Latin American and Caribbean Anthropology, 18 (1), 67-89. https://doi.org/10.1111/ilca.12003

Latour, B. (2009). Politics of Nature: How to Bring the Sciences into Democracy. Harvard University Press. 
eTropic 20.2 (2021) Special Issue: Tropical Imaginaries and Climate Crisis

Leal, C. (2018). Landscapes of Freedom: Building a Postemancipation Society in the Rainforests of Western Colombia. University of Arizona Press. https://doi.org/10.2307/i.ctt1zxsmqx

Leal, C., Ausdal, S. V., Miraglia, M. M., \& Silva, S. D. e. (2020). Africa and the Americas in the Columbian Exchange: An Interview with Judith Carney. Historia Ambiental Latinoamericana y Caribeña (HALAC) Revista de La Solcha, 10(3), 380-401. https://doi.org/10.32991/2237-2717.2020v10i3.p380-401

Lidström, S., West, S., Katzschner, T., Pérez-Ramos, M. I., \& Twidle, H. (2016). Invasive Narratives and the Inverse of Slow Violence: Alien Species in Science and Society. Environmental Humanities, 7 (1), 1-40. https://doi.org/10.1215/22011919-3616317

López-Angarita, J., Roberts, C.M., Tilley, A., Hawkins, J.P., \& Cooke, R.G. (2016). Mangroves and people: Lessons from a history of use and abuse in four Latin American countries. Forest Ecology and Management, 368, 151-162. https://doi.org/10.1016/i.foreco.2016.03.020

Lynn, M. (2005). The British Empire in the 1950s: Retreat or Revival? Palgrave Macmillan UK.

Macpherson, A. (2018). Art, Trees, and the Enchantment of the Anthropocene: Caroline Wendling's White Wood. Environmental Humanities, 10(1), 241-256. https://doi.org/10.1215/22011919-4385552

Marder, M. (2013). Plant-Thinking: A Philosophy of Vegetal. Columbia University Press.

Merecí-Guamán, J., Casanoves, F., Delgado-Rodríguez, D., Ochoa, P., \& Cifuentes-Jara, M. (2021). Impact of Shrimp Ponds on Mangrove Blue Carbon Stocks in Ecuador. Forests, 12(7), 816. https://doi.org/10.3390/f12070816

Montgomery, E. J. (2019). Gothic 'Voodoo' in Africa and Haiti. eTropic: Electronic Journal of Studies in the Tropics, 18(1), 11-28. https://doi.org/10.25120/etropic.18.1.2019.3666

Nixon, R. (2011). Slow Violence and the Environmentalism of the Poor. Harvard University Press. https://doi.org/10.4159/harvard.9780674061194

Nyanga, C. (2020). The Role of Mangroves Forests in Decarbonizing the Atmosphere. In M. Bartoli, M. Frediani \& L. Rosi (Eds.), Carbon-Based Material for Environmental Protection and Remediation, (pp. 153-164). London: INTECHOPEN. https://doi.org/10.5772/intechopen.92249

Ocampo-Thomason, P. (2006). Mangroves, People and Cockles: Impacts of the ShrimpFarming Industry on Mangrove Communities in Esmeraldas Province, Ecuador. In P. Ocampo-Thomason, Environment and Livelihoods in Tropical Coastal Zones: Managing Agriculture-Fishery-Aquaculture Conflicts, (pp. 140-152). CABI. https://doi.org/10.1079/9781845931070.0140

Ortega, J. (2006). Transatlantic Translations: Dialogues in Latin American Literature. Reaktion Books.

Prieto, E. (2003). Landscaping identity in contemporary Caribbean literature. In K. Salhi (Ed.), Francophone Post-Colonial Cultures: Critical Essays, (pp. 141-52). Lexington Books.

Queiroz, L. de S., Rossi, S., Calvet-Mir, L., Ruiz-Mallén, I., García-Betorz, S., Salvà-Prat, J., \& Meireles, A. J. de A. (2017). Neglected ecosystem services: Highlighting the sociocultural perception of mangroves in decision-making processes. Ecosystem Services, 26, 137-145. https://doi.org/10.1016/j.ecoser.2017.06.013

Routledge, P. (2011). Translocal Climate Justice Solidarities. In J.S. Dryzek, R.B. Norgaard \& D. Schlosberg (Eds.), The Oxford Handbook of Climate Change and Society, (pp. 384-398). Oxford University Press. https://doi.org/10.1093/oxfordhb/9780199566600.003.0026 
eTropic 20.2 (2021) Special Issue: Tropical Imaginaries and Climate Crisis

Ryan, J. R. (2015). Plant-Art: The Virtual and the Vegetal in Contemporary Performance and Installation Art. Resilience: A Journal of the Environmental Humanities, 2(3), 40. https://doi.org/10.5250/resilience.2.3.0040

Singh, S. J., Haberl, H., Chertow, M., Mirtl, M., \& Schmid, M. (Eds.). (2013). Long Term Socio-Ecological Research: Studies in Society-Nature Interactions Across Spatial and Temporal Scales. Springer Netherlands. https://doi.org/10.1007/978-94-007$1177-8$

Sousa-Santos, B. de (2014). Epistemologies of the South: Justice Against Epistemicide. Routledge.

Spalding, M., Kainuma, M., \& Collins, L. (2010). World Atlas of Mangroves. Earthscan. https://doi.org/10.4324/9781849776608

Spivak, G.C. (1988). Can the subaltern speak? In C. Nelson \& L. Grossberg (Eds.), Marxism and the Interpretation of Culture, (pp. 271-313). University of Illinois Press. https://doi.org/10.1007/978-1-349-19059-1 20

Svampa, M. (2019). Neo-extractivism in Latin America: Socio-environmental Conflicts, the Territorial Turn, and New Political Narratives. Cambridge University Press. https://doi.org/10.1017/9781108752589

Tsing, A. L. (2015). The Mushroom at the End of the World: On the Possibility of Life in Capitalist Ruins. Princeton University Press. https://doi.org/10.2307/j.ctvc77bcc

Tsing, A., Deger, J., Saxena, A. K. \& Zhou, F. (2021). Feral Atlas: The More-Than-Human Anthropocene. Stanford University Press. http://doi.org/10.21627/2020fa

Wake, T. A., \& Kay, M. (2013). Archaeological Investigations Provide Late Holocene Baseline Ecological Data for Bocas del Toro, Panama. Bulletin of Marine Science, 89 (4), 1015-1035.

Ward, R. D., Friess, D. A., Day, R. H., \& Mackenzie, R. A. (2016). Impacts of climate change on mangrove ecosystems: A region by region overview. Ecosystem Health and Sustainability, 2(4), e01211. https://doi.org/10.1002/ehs2.1211

\section{Acknowledgments}

I would like to thank photographer Felipe Jácome for granting permission to publish one of his photographs with this essay. Gracias to the people of the CayapasMangrove reserve. Gracias also to my colleague Carlos Garrido Castellano for providing feedback during the completion of this article.

Dr Yairen Jerez Columbié's work focuses on marginalised knowledge, cultural exchanges and ecocritical approaches in Latin America, the Caribbean and the Atlantic World. She is the author of the monograph Essays on Transculturation and Catalan-Cuban Intellectual History (Palgrave Macmillan, 2021), which explores the interplay between transcultural identities, interculturality and community-making processes. 